\title{
FAKTOR - FAKTOR YANG BERHUBUNGAN DENGAN STATUS GIZI IBU HAMIL DI PUSKESMAS SIDOREJO KOTA LUBUKLINGGAU
}

\author{
Zuraidah dan Yeni Elviani \\ Politeknik Kesehatan Palembang, Prodi Keperawatan Lubuklinggau, \\ Jl. Stadion Bumi Silampari Kel. Air Kuti Lubuklinggau Timur Lubuklinggau 31626 \\ szuraidah84@yahoo.co.id
}

\begin{abstract}
Abstrac : The nutritional status of pregnant women is one of the indicators to measure the nutritional status of the community. If the input of nutrition for pregnant women of the food is not balanced with the needs of the body, there will be a deficiency of nutrients. Maternal Mortality become one important indicator in determining the degree of public health. According to the World Health Organization (WHO) in 2005 in developed countries the maternal mortality rate ranged from 5-10 per 100,000 live births, while in countries emerging range between 750-1000 per 100,000 live births (Winkjosastro, 2005). The purpose of this study to determine the factors-factors related to the nutritional status of pregnant women. The independent variables of this study are education, income and knowledge while the dependent variable is the nutritional status of pregnant women. This research uses a survey method with cross sectional analytic. The population in this study were all pregnant women at health centers Sidorejo Lubuklinggau is numbered 40 pregnant women. The sample used is total sam-pling. Collecting data by distributing questionnaires to the respondents. The survey results revealed that respondents with low education, there are $23(57.5 \%)$, lower income as many as 30 (75\%), and respondents who have enough knowledge-less 27 (67.5\%), and respondents malnutrition status as $22(55 \%)$. After testing the chi square statistic diketahahui these three variables have a significant association with the nutritional status of pregnant women. Expected for health centers to provide health education on nutrition in pregnant women, and also provide nutritious supplementary feeding program for pregnant women
\end{abstract}

Keywords : Education, Income, knowledge, Nutritional Status

\begin{abstract}
Abstrak :Status gizi ibu hamil merupakan salah satu indikator dalam mengukur status gizi masyarakat. Jika masukan gizi untuk ibu hamil dari makanan tidak seimbang dengan kebutuhan tubuh maka akan terjadi defisiensi zat gizi. Angka Kematian Ibu menjadi salah satu indikator penting dalam menentukan derajat kesehatan masyarakat. Menurut World Health Organization (WHO) pada tahun 2005 di negara-negara maju angka kematian maternal berkisar antara 5-10 per 100.000 kelahiran hidup, sedangkan di negara-negara sedang berkembang berkisar antara 750-1000 per 100.000 kelahiran hidup (Winkjosastro, 2005). Tujuan penelitian ini untuk mengetahui faktor-faktor yang berhubungan dengan status gizi pada ibu hamil. Variabel independen dari penelitian ini adalah pendidikan, pendapatan dan pengetahuan sedangkan variabel dependen adalah status gizi ibu hamil. Jenis penelitian ini meng-gunakan metode survey analitik dengan pendekatan cross sectional. Populasi pada penelitian ini adalah seluruh ibu hamil di Puskesmas Sidorejo Kota Lubuklinggau yaitu berjumlah 40 ibu hamil. Sampel yang digunakan adalah total sampling. Pengumpulan data yaitu dengan cara menyebarkan kuesioner pada responden. Hasil penelitian diketahui bahwa responden yang memiliki pendidikan rendah ada 23 $(57,5 \%)$, pendapatan rendah sebanyak $30(75 \%)$, dan responden yang memiliki pengetahuan cukup-kurang sebanyak $27(67,5 \%)$, dan responden status gizi kurang sebanyak $22(55 \%)$. Setelah dilakukan uji statistik chi square diketahahui ketiga variabel tersebut mempunyai hubungan yang bermakna dengan status gizi ibu hamil. Diharapkan bagi Puskesmas untuk memberikan penyuluhan kesehatan tentang gizi pada ibu hamil, dan juga memberikan program pemberian makanan tambahan bergizi pada ibu hamil.
\end{abstract}

Kata Kunci : Pendidikan, Pendapatan, pengetahuan, Status Gizi 
Kesejahteraan dan derajat gizi masyarakat dapat diukur melalui status gizi terutama pada status gizi anak, balita, dan bumil. Kebutuhan gizi seorang wanita meningkat selama masa kehamilan. Seorang ibu hamil akan melahirkan bayi yang sehat bila tingkat kesehatan dan gizinya selama hamil berada pada kondisi yang baik (Wahyuni, 2008).

Ibu hamil yang menderita KEK dan Anemia mempunyai resiko kesakitan yang lebih besar terutama pada trimester III kehamilan dibandingkan dengan ibu hamil normal. Akibatnya mereka mempunyai resiko yang lebih besar untuk melahirkan bayi dengan BBLR, kematian saat persalinan, pendarahan, pasca persalinan yang sulit karena lemah dan mudah mengalami gangguan kesehatan (Depkes, 2008).

Gizi pada waktu hamil harus ditingkatkan hingga 300 kalori perhari, Ibu hamil seharusnya mengkomsumsi makanan yang mengandung protein, zat besi, dan minum cukup cairan (Kusmiati, 2009). Kebutuhan gizi selama kehamilan akan meningkat perhari, meskipun semua orang Indonesia sudah mengetahui manfaat gizi bagi ibu hamil namun sampai saat ini masih banyak ibu hamil yang mengalami masalah gizi (Damanik, 2009).

Menurut badan kesehatan dunia WHO melaporkan bahwa ibu hamil yang mengalami defisiensi besi sekitar 35-75\% (Purwoko, 2011). Menurut penelitian yang dilakukan di Boston tahun 2005 menunjukkan bahwa ibu hamil dengan kurang gizi dapat melahirkan bayi lahir mati, meninggal setelah beberapa hari lahir, dan bayi lahir dengan kecacatan (Hariyani, 2012).

Gizi kurang pada ibu hamil dapat menyebabkan resiko dan komplikasi pada ibu, seperti KEK, anemia, perdarahan dan berat badan ibu tidak bertambah secara normal serta terkena penyakit infeksi. Ibu yang sejak awal mengalami KEK akan lebih beresiko melahirkan bayi dengan berat badan lahir rendah (BBLR) yaitu berat badan bayi $<2500$ gram. Kekurangan gizi pada ibu hamil dapat mempengaruhi pertumbuhan janin dan dapat menimbulkan keguguran atau abortus.
Hasil kunjungan ibu hamil di seluruh Puskesmas di Kota Lubuklinggau tahun 2013 didapatkan data dan gambaran bahwa status gizi pada Ibu hamil berdasarkan sekitar wilayah kerja Puskesmas di Kota Lubuklinggau pada tahun 2013, dapat dilihat pada tabel 1 dibawah ini

Tabel 1. Jumlah Ibu Hamil Yang Mengalami Kurang Energi Kronis(KEK) Tahun 2013

\begin{tabular}{lccc}
\hline Puskesmas & $\begin{array}{c}\text { SasaranBu } \\
\text { mil }\end{array}$ & $\begin{array}{c}\text { Jumlah } \\
\text { Bumil }\end{array}$ & $\begin{array}{c}\text { Bumil } \\
\text { KEK }\end{array}$ \\
\hline Prumnas & 683 & 57 & - \\
Siderejo & 477 & 40 & 12 \\
Citra Medika & 315 & 25 & - \\
Simpang Periuk & 320 & 27 & 2 \\
Sumber Waras & 615 & 52 & - \\
Swasi Taba & 520 & 60 & - \\
Megang & 306 & 62 & - \\
Petanang & 721 & 28 & - \\
\hline Jumlah & & 351 & 14 \\
\hline
\end{tabular}

Penelitian ini bertujuan untuk mengetahui faktor-faktor yang berhubungan dengan status gizi ibu hamil di Puskesmas Sidorejo Kota Lubuklinggau Tahun 2014”.

\section{BAHAN DAN CARA KERJA}

Desain penelitian yang digunakan adalah surveyanalitik dengan pendekatan cross sectional Populasi yang digunakan dalam penelitian ini adalah Ibu hamil Trimester I s/d III di Puskesmas Sidorejo Kota Lubuklinggau Tahun 2014 berjumlah 40 Ibu hamil. sampel digunakan dengan cara total sampling yaitu sampel yang diambil secara keseluruhan dari Ibu hamil yang mengalami kurang energi kronis (KEK) di Puskesmas Sidorejo Kota Lubuklinggau Tahun 2014.

\section{HASIL}

\section{Analisis Univariat}

Hasil penelitian diperoleh karakrteristik responden sebagai berikut : Pendidikan ibu yang rendah sebanyak $23 \quad(57,5 \%)$ respon-den dan Pendidikan ibu yang tinggi sebanyak 17 (42,5\%) responden. Pendapatan ibu rendah sebanyak $23(57,5 \%)$ responden dan Pendidikan ibu yang tinggi sebanyak $17(42,5 \%)$ responden. Pengetahuan ibu yang kurang sebanyak $16(40 \%)$ responden, Pengetahuan ibu yang baik sebanyak $13(32,5 \%)$ responden, Pengetahuan ibu 
yang cukup sebanyak $11(27,5 \%)$ responden. Status Gizi baik sebanyak 18 (45\%) responden dan Status Gizi kurang sebanyak $22(55 \%)$

\section{Analisa Bivariat}

Tabel 1. Distribusi Responden Menurut Umur Ibu, Paritas Ibu dan Status Gizi Ibu Hamil.

\begin{tabular}{|c|c|c|c|c|c|c|c|}
\hline \multirow[t]{2}{*}{ variabel } & \multicolumn{2}{|c|}{$\begin{array}{c}\text { Status } \\
\text { gizi } \\
\text { (baik) }\end{array}$} & \multicolumn{2}{|c|}{$\begin{array}{c}\text { Status } \\
\text { Gizi } \\
\text { ( Kurang) }\end{array}$} & \multicolumn{2}{|c|}{ Total } & \multirow[t]{2}{*}{ P value } \\
\hline & $\mathrm{f}$ & $\%$ & $f$ & $\%$ & $\mathrm{f}$ & $\%$ & \\
\hline \multicolumn{8}{|l|}{ Pendidikan } \\
\hline Tinggi & 13 & 76,5 & 4 & 23,5 & 17 & 100 & 0,002 \\
\hline Rendah & 5 & 21,7 & 18 & 78,3 & 23 & 100 & \\
\hline \multicolumn{8}{|l|}{ Pendapatan } \\
\hline Tinggi & 9 & 90 & 1 & 10 & 10 & 100 & 0,002 \\
\hline Rendah & 9 & 30 & 21 & 70 & 30 & 100 & \\
\hline \multicolumn{8}{|l|}{ Pengetahuan } \\
\hline Baik & 10 & 76,9 & 3 & 23,1 & 13 & 100 & 0,013 \\
\hline Cukup Kurang & 8 & 29,6 & 197 & 0,4 & 27 & 100 & \\
\hline
\end{tabular}

Dari tabel 1 Hasil analisis dari hubungan antara pendidikan dengan status gizi ibu hamil diketahui pada responden dengan pendidikan tinggi ada $13(76,5 \%)$ gizi baik, sedangkan pada responden dengan pendapatan rendah ada $5(21,7 \%)$ gizi baik. Hasil uji statistik didapatkan $p=0,002<\alpha=0,05$, sehingga dapat disimpulkan ada hubungan antara pendidikan dengan status gizi pada ibu hamil. Hasil analisis dari hubungan antara pendapatan dengan status gizi ibu hamil diketahui pada responden dengan pendapatan tinggi ada 9 ibu hamil $(90,0 \%)$ gizi baik, sedangkan pada responden dengan pendapatan rendah ada 9 ibu hamil $(30,0 \%)$ gizi baik.Hasil uji statistik didapatkan $p=0,002<\alpha=0,05$, sehingga dapat disimpulkan ada hubungan antara pendapatan dengan status gizi pada ibu hamil.Hasil analisis hubungan antara pengetahuan dengan status gizi ibu hamil diketahui pada responden dengan pengetahuan baik ada $10 \mathrm{ibu}$ hamil $(76,9 \%)$ status gizinya baik, sedangkan pada responden dengan pengetahuan cukupkurang ada 8 ibu hamil $(29,6 \%)$ status gizinya baik. Hasil uji statistik didapatkan $p=0,013<\alpha=0,05$, sehingga dapat disimpulkan ada hubungan antara pengetahuan dengan status gizi pada ibu hamil.

\section{PEMBAHASAN}

Pendidikan dapat mempengaruhi se- seorang terhadap perilaku kesehatan karena dengan pendidikan dapat memotivasi sikap seseorang dalam melakukan perannya untuk hidup sehat. Makin tinggi tingkat pendidikan seseorang, makin mudah memerima informasi sehingga semakin banyak pula pengetahuan yang diterima. Sebaliknya pendidikan yang kurang akan menghambat perkembangan sikap seseorang terhadap nilai-nilai baru. Latar belakang pendidikan yang lebih tinggi diharapkan pengetahuan atau informasi gizi yang dimiliki lebih baik sehingga bisa memenuhi asupan gizinya (Umar, 2007).

Faktor yang berperan dalam menentukan status kesehatan seseorang adalah tingkat sosial ekonomi, dalam hal ini adalah daya beli keluarga. Kemampuan keluarga untuk membeli bahan makanan antara lain tergantung pada besar kecilnya pendapatan keluarga, harga bahan makanan itu sendiri, serta tingkat pengelolaan sumber daya lahan dan pekarangan. Keluarga dengan pendapatan terbatas kemungkinan besar kurang dapat memenuhi kebutuhan makanannya terutama untuk memenuhi kebutuhan zat gizi dalam tubuhnya (Fikawati, 2012).

Pendapatan merupakan faktor yang paling menentukan kualitas dan kuantitas hidangan. Semakin banyak mempunyai uang berarti semakin baik makanan yang diperoleh. Dengan kata lain semakin tinggi penghasilan, semakin besar pula persentase dari penghasilan tersebut untuk membeli daging, buah, sayuran dan beberapa jenis bahan makanan lainnya (Fikawati, 2012).

Masalah gizi di Indonesia dan di negara berkembang pada umumnya masih didominasi oleh masalah Kurang Energi Protein (KEP), Masalah Anemia Besi, masalah Gangguan Akibat Kekurangan Yodium (GAKY), masalah Kurang Vitamin A (KVA) (Nyoman S, 2002).

Rawan pangan dan gizi masih menjadi salah satu masalah besar bangsa ini. Masalah gizi berawal dari ketidakmampuan rumah tangga mengakses pangan, baik karena masalah ketersediaan di tingkat lokal, kemiskinan, pendidikan dan pengetahuan akan pangan dan gizi, serta perilaku masya- 
rakat. Kekurangan gizi mikro seperti vitamin A, zat besi dan yodium menambah besar permasalahan gizi di Indonesia. Dengan demikian masalah pangan dan gizi merupakan permasalahan berbagai sektor dan menjadi tanggung jawab bersama pemerintah dan masyarakat (Suzeta, 2007).Menurut pendapat Mulyaningrum dan Alchadi (2009) pentingnya status gizi ibu perlu dilihat dari berbagai aspek. Selain akses terhadap keamanan pangan dan terhadap pelayanan kesehatan setinggi-tingginya merupakan hak azasi dasar setiap orang, status gizi ibu juga mempunyai dampak secara sosial dan ekonomi (pendapatan keluarga).Berbagai penelitian semakin menunjukkan bahwa status kesehatan dan resiko kematian dirinya, tetapi juga terhadap kelangsungan hidup dan perkembangan janin yang dikandungnya dan lebih jauh lagi terhadap pertumbuhan janin tersebut sampai usia dewasa. Status sosial ekonomi ini meliputi : Pendidikan dan pendapatan (Syafrudin, 2010).Faktor sosial ekonomi yaitu meliputi data sosial yaitu, keadaan penduduk, keadaan keluarga, pendidikan, perumahan, dapur penyimpanan makanan, sumber air, kakus. Sementara data ekonomi meliputi pekerjaan, pendapatan keluarga, kekayaan, pengeluaran dan harga makanan yang tergantung pada pasar dan variasi musim (Supriasa, 2002). Menurut Dalimunthe (2005), kehidupan sosial ekonomi adalah suatu kehidupan sosial ekonomi masyarakat yang menggunakan indikator pendidikan, pekerjaan dan penghasilan sebagai tolak ukur. Menurut pendapat Junaidi (2005), keluarga adalah individu dengan jati diri yang khas yang memiliki karakteristik tersendiri. Karakteristik adalah sifat individu yang relatif tidak berubah, atau yang dipengaruhi lingkungan seperti umur, jenis kelamin, suku bangsa, kebangsaan, pendidik-an dan lain-lain. Perkembangan intelek-tual akan kesadaran lingkungan seorang individu seringkali dilepaskan dan bahkan dipisahkan dengan masalah keluarga. Hal-hal semacam inilah yang sering menim-bulkan masalah-masalah sosial, karena kehi-langan pijakan. Oleh karena itu adalah bijaksana kalau dilihat dan dikembalikan peranan keluarga dan proporsi yang sebenar-nya dengan skala prioritas yang pas. Fungsi ekonomi yaitu : 1). kebutuhan makan dan minum, 2). kebutuhan pakaian untuk menu-tup tubuh, 3). Kebutuhan tempat tinggal. Sehubungan dengan fungsi tersebut maka orang tua diwajibkan untuk berusaha keras agar supaya setiap anggota keluarga dapat cukup makan dan minum, cukup pakaian serta tempat tinggal.

Pengetahuan adalah merupakan hasil dari tahu, dan ini terjadi setelah orang melakukan penginderaan terhadap suatu objek tertentu. Penginderaan terjadi melaui pancaindera manusia, yaitu indera penglihatan, pendengaran, penciuman, rasa dan raba. Sebagian besar pengetahuan manusia diperoleh melalui mata dan telinga. Pengetahuan atau kognitif merupakan domain yang sangat penting dalam membentuk tindakan seseorang (Notoatmodjo, 2005). Pengetahuan gizi merupakan pengetahuan tentang hubungan konsumsi makanan dengan kesehatan tubuh. Ibu hamil dengan pengetahuan gizi baik diharapkan dapat memilih asupan makanan yang bernilai gizi baik dan seimbang bagi dirinya sendiri, janin dan keluarga. Pengetahuan gizi yang baik dapat membantu seseorang belajar bagaimana menyimpan, mengolah serta menggunakan bahan makanan yang berkualitas untuk dikonsumsi (Wahyuni, 2008). Pengetahuan yang kurang menyebabkan bahan makanan bergizi yang tersedia tidak dikonsumsi secara optimal. Pemilihan bahan makanan dan pola makan yang salah cukup berperan dalam terjadinya kekurangan gizi (Depkes, 2005). Pengetahuan ibu terhadap gizi dan permasalahannya sangat berpengaruh terhadap status gizi keluarga. Ibu hamil yang memiliki pengetahuan gizi yang baik akan mampu memilih jenis makanan yang tepat untuk dirinya dan janinnya baik dari segi kuantitas maupun kualitas.Pengetahuan gizi merupakan pengetahuan tentang hubungan konsumsi makanan dengan kesehatan tubuh. Ibu hamil dengan pengetahuan gizi baik diharapkan dapat memilih asupan makanan 
yang bernilai gizi baik dan seimbang bagi dirinya sendiri beserta janin dan keluarga, dengan pengetahuan gizi yang cukup dapat membantu seseorang belajar bagaimana menyimpan, mengolah serta menggunakan bahan makanan yang berkualitas untuk dikonsumsi menurut kebutuhannya (Hastuti, 2006). Kurangnya pengetahuan dan salah konsepsi tentang kebutuhan pangan dan nilai pangan adalah umum dijumpai setiap negara di dunia. Kemiskinan dan kekurangan persediaan pangan yang bergizi merupakan faktor penting dalam masalah kurang gizi / lain sebab yang penting dari gangguan gizi adalah kekurangan pengetahuan tentang gizi atau kemampuan untuk menerapkan informasi tersebut dalam kehidupan sehari-hari (Suhardjo, 2006). Dengan pengetahuan gizi yang cukup diharapkan seseorang dapat mengubah perilaku yang kurang benar sehingga dapat memilih bahan makanan bergizi serta menyusun menu seimbang sesuai dengan kebutuhan dan selera serta akan mengetahui akibat adanya kurang gizi. Pemberian pengetahuan gizi yang baik diharapkan dapat mengubah kebiasaan makan yang semula kurang menjadi lebih baik (Depkes, 2005). Marsianto (2004) dalam penelitiannya menyebutkan bahwa yang mempengaruhi status gizi ibu hamil adalah pengetahuannya mengenai makanan yang harus dikonsumsinya selama hamil sehingga dapat mencegah terjadinya berat bayi lahir rendah.

Maka dalam kondisi tersebut diatas, masih diperlukannya penanganan yang profesional dan pemberitahuan dalam pengetahuan secara khusus bahwa perawat sebagai salah satu tenaga kesehatan untuk memberikan penyuluhan terhadap ibu hamil tentang pentingnya makanan yang bergizi dalam keadaan hamil.

Status gizi ibu hamil merupakan salah satu indikator dalam mengukur status gizi masyarakat. Jika masukan gizi untuk ibu hamil dari makanan tidak seimbang dengan kebutuhan tubuh maka akan terjadi defisiensi zat gizi. Angka Kematian Ibu menjadi salah satu indikator penting dalam menentukan derajat kesehatan masyarakat
(Winkjosastro, 2005). Enam penyebab tingginya angka kematian ibu di Indonesia adalah perdarahan, eklampsia, aborsi tidak aman (unsafe abortion), partus lama, dan infeksi. Faktor yang lain yang meningkatkan Angka Kematian Ibu (AKI) adalah buruknya gizi perempuan, yang dikenal dengan Kekurangan Energi Kronik (KEK), dan anemia (Sadli, 2010). Masalah gizi yang sering dihadapi ibu hamil yaitu Kekurangan Energi Kronik (KEK) dan anemia gizi. Adapun faktor penyebab terjadinya status gizi kurang (KEK) pada ibu hamil sangat kompleks diantaranya ketidakseimbangan asupan zatzat gizi, faktor penyakit pencernaan, absorsi dan penyakit infeksi. Sedangkan ada beberapa faktor yang mempengaruhi gizi ibu hamil, diantaranya adalah berat badan, budaya pantang makan, status ekonomi, pengetahuan zat gizi dalam makanan, umur, suhu lingkungan, aktivitas, serta status kesehatan (Proverawati, 2009). Gizi kurang pada ibu hamil dapat menyebabkan resiko dan komplikasi pada ibu antara lain: anemia, pendarahan, berat badan ibu tidak bertambah secara normal, dan terkena penyakit infeksi. Pengaruh gizi kurang terhadap proses persalinan dapat mengakibatkan persalinan sulit dan lama, persalinan sebelum waktunya (premature), pendarahan setelah persalinan, serta persalinan dengan operasi cenderung meningkat. Kekurangan gizi pada ibu hamil juga dapat mempengaruhi proses pertumbuhan janin dan dapat menimbulkan keguguran, abortus, bayi lahir mati, kematian neonatal, cacat bawaan, anemia pada bayi, asfiksia intra partum (mati dalam kandungan), lahir dengan berat badan lahir rendah (BBLR) (Kristiyanasari, 2010). Penyebab tidak langsung dari kematian ibu dari sisi masyarakat antara lain tingkat sosial ekonomi, tingkat pendidikan, faktor budaya dan peran kaum ibu yang tidak menguntungkan dan transportasi resiko kematian ibu makin besar dengan adanya anemia, kekurangan energi kronik (KEK) dan penyakit menular seperti malaria, tuberkolosis (TB) Hepatitis, dan HIV/AIDS Pada tahun 2005 misalnya anemia pada ibu hamil mencapai $51 \%$ dan pada ibu nifas $45 \%$, pada tahun 
2012, 17,6\% wanita usia subur menderita (KEK) (Siregar, 2007).

Dasar perlunya gizi seimbang bagi ibu hamil pada masa kehamilan merupakan masa terjadinya stress fisiologi pada ibu hamil. Karena masa penyesuaian tubuh ibu terhadap perubahan fungsi tubuh. Ibu hamil sebenarnya sama dengan ibu yang tidak hamil, namun kualitas dan kuantitasnya ditingkatkan melalui pola makan dengan kebiasaan makan yang baik, pola makan dan kebiasaan makan yang baik disini adalah menu seimbang dengan jenis makan yang bervariasi (Sari, 2009). Ibu hamil membutuhkan tambahan energi dan zat gizi yang seimbang untuk pertumbuhan dan perkembangan janin dengan tetap memperhatikan kebutuhan zat gizi ibu (Ramayulis, 2009).

Dalam kondisi tersebut diatas, masih diperlukannya penanganan secara khusus bahwa perawat sebagai salah satu tenaga kesehatan dalam melaksanakan kegiatan penyuluhan kesehatan tentang kurang gizi dalam keadaan hamil dan memberikan program pemberian makanan tambahan bagi ibu hamil.

\section{Hubungan antara pendidikan, pendapatan dan pengetahuan dengan status gizi ibu hamil}

Hasil uji statistik disimpulkan ada hubungan antara pendidikan dengan status gizi pada ibu hamil. Pendidikan berhubungan dengan status gizi ibu hamil karena tingkat pendidikan yang baik maka ibu akan mancari tahu dari buku, koran ataupun majalah tentang gizi. Jika ibu ke Posyandu atau tempat pelayanan kesehatan yang membahas masalah gizi akan aktif bertanya dan mengikuti penyuluhan tentang gizi.

Hal ini sesuai dengan pendapat Llewellyn (2003) yang menyebutkan bahwa seberapa efisien seorang wanita itu memilih dan membeli makanan yang tepat merupakan hasil dari pendidikannya.

Pendapatan merupakan faktor yang paling menentukan kualitas dan kuantitas hidangan. Semakin banyak mempunyai uang berarti semakin baik makanan yang diperoleh. Dengan kata lain semakin tinggi penghasilan, semakin besar pula persentase dari penghasilan tersebut untuk membeli daging, buah, sayuran dan beberapa jenis bahan makanan lainnya (Fikawati, 2012). Setelah dilakukan hasil uji statistik didapatkan $p=0,002<\alpha=0,05$, sehingga dapat disimpulkan ada hubungan antara pendapatan dengan status gizi pada ibu hamil. Hasil penelitian ini sama dengan penelitian yang pernah dilakukan oleh Asriningtyas (2010) menyebutkan adanya hubungan yang bermakna antara pendapatan dengan status gizi pada ibu hamil di Yogyakarta.

Pengetahuan gizi merupakan pengetahuan tentang hubungan konsumsi makanan dengan kesehatan tubuh. Ibu hamil dengan pengetahuan gizi baik diharapkan dapat memilih asupan makanan yang bernilai gizi baik dan seimbang bagi dirinya sendiri, janin dan keluarga. Pengetahuan gizi yang baik dapat membantu seseorang belajar bagaimana menyimpan, mengolah serta menggunakan bahan makanan yang berkualitas untuk dikonsumsi (Wahyuni, 2008). Pengetahuan yang kurang menyebabkan bahan makanan bergizi yang tersedia tidak dikonsumsi secara optimal. Pemilihan bahan makanan dan pola makan yang salah cukup berperan dalam terjadinya anemia (Depkes, 2005).

Pengetahuan ibu terhadap gizi dan permasalahannya sangat berpengaruh terhadap status gizi keluarga. Ibu hamil yang memiliki pengetahuan gizi yang baik akan mampu memilih jenis makanan yang tepat untuk dirinya dan janinnya baik dari segi kuantitas maupun kualitas. Selain pengetahuan gizi, pengetahuan kesehatan kehamilan juga perlu bagi ibu hamil. Dengan demikian, pengetahuan gizi dan kesehatan merupakan salah satu faktor protektif dalam mempertahankan kualitas kehamilan.

Pengetahuan memiliki pengaruh yang sangat besar terhadap kesehatan. Hasil uji statistik didapatkan dari $p=0,013<\alpha=0,05$, sehingga dapat disimpulkan ada hubungan antara pengetahuan dengan status gizi ibu hamil.Hasil penelitian ini sama dengan penelitian yang pernah dilakukan oleh Kusumawati (2010), Berdasarkan hasil uji statistik dengan menggunakan uji Rank Spearman pada taraf kesalahan 5\% disim- 
pulkan adanya hubungan antara pengetahuan gizi ibu dengan berat bayi lahir nilaip sebesar 0,014. Begitu hasil penelitian Marsianto (2006) yang menyebutkan juga bahwa upaya untuk meningkatkan kualitas manusia yang dimulai dari status gizi bayi baru lahir ada hubungannya dengan pengetahuan gizi ibu.Dengan pengetahuan gizi yang cukup diharapkan seseorang dapat mengubah perilaku yang kurang benar sehingga dapat memilih bahan makanan bergizi serta menyusun menu seimbang (Depkes, 2004)

\section{KESIMPULAN}

Penelitian tentang hubungan faktor

\section{DAFTAR RUJUKAN}

Adriani, M. 2012. Peranan Gizi Dalam Siklus Kehidupan. Penerbit Kencana Prenada Media Group.Jakarta.

Almatsier, S. 2010. Prisnip Dasar Ilmu Gizi. Cet.Ke.9.Penerbit Gramedia Pustaka Utama. Jakarta.

Anastasia, 2010. Hubungan Pengetahuan Dengan Status Gizi Ibu Hamil di Puskesmas Bahu Manado.Jurnal Penelitian (online):(http://www.unman.ac.id, diakses pada tanggal 1 Juli 2014)

Asfuah,2009.

StatusEkonomi

Keluarga.(http://www.sosek.com,diaksestangg al1Juli 2012

Asriningtyas, 2010. Hubungan Pendapatan dengan Status Gizi pada Ibu Hamil di Yogyakarta.

Azwar, 2007. Anemia Gizi Pada Ibu Hamil.(http://www.anemia_bumil,diaksestang gal11 Juli 2014)

Beck, 2004. Status Gizi. (http://www.statusgizi.co.id,diakses pada tanggal 2 Juli

Budiani, 2010. Hubungan Pengetahuan dengan Status GizilbuHamil.Jurnal Penelitian (online) :(http://www.Hubungan-pengetahuan-denganstatus-gizi.ac.id,diakses padatanggal 2 Juli 2014)

Budiyanto. 2003. Faktor-faktor yang berhubungan dengan status gizi ibu hamil. Penerbit Raja Grafindo Persada.Jakarta. faktor yang berhubungan dengan status gizi ibu hamil di Puskesmas Sidorejo Kota Lubuklinggau Tahun 2014 dapat disimpulkan ada hubungan antara pendidikan, dan pengetahuan dengan status gizi ibu hamil.

Diharapkan bagi Dinas Kesehatan Kota Lubuklinggau untuk memberikan program pemberian makanan tambahan bergizi pada ibu hamil di Puskesmas Sidorejo Kota Lubuklinggau tahun 2014. Puskesmas untuk memberikan penyuluhan kesehatan tentang gizi pada ibu hamil, dan juga memberikan program pemberian makanan tambahan bergizi pada ibu hamil.

Dalimunthe, 2005.

SosialEkonomi,(http://www.sosialekonomi.com ,diakses pada tanggal 2 Juli 2014)

Damanik, R. 2009 HubunganKecukupanGizi,Kenaikan Berat Badan dan Status Gizi Ibu Hamil Trimester III dengan Berat Badan Lahir Bayi di Puskesmas Keliling Kecamatan Keeling Kabupaten Jepara. JurnalPenelitian (online):(http://eprints.undip.ac.id,diakses tanggal 4 Januari2014)

Depkes RI. 2003. Program Penanggulangan Anemia Gizi Pada Wanita Usia Subur(WUS).

Fikawati, S. 2013. Gizi dan Kesehatan Masyarakat. Penerbit Raja Grafindo Persada. Jakarta.

Jurnal Penelitian (online): (pendapatan dengan status gizi.co.id, diakses pada tanggal 1 Juli 2014)

Kristiyanasari, W. 2010. Gizi Ibu Hamil. Penerbit NuhaMedika. Yogyakarta.

Kusmiyati, Y. 2009. Perawatan ibu hamil (asuhan ibu hamil). Penerbit Fitramaya.Yogyakarta.

Nanni, 2007. Dampak Anemia danKekurangan Energi Kronis pada IbuHamil.Penerbit Raja Grafindo Persada.Jakarta.

Notoatmodjo, 2005. Pendidikan dan Perilakukesehatan, Penerbit RinekaCipta.Jakarta.

Wirjatmadi, 2012. Gizi dan Kesehatan Masyarakat, Penerbit Raja Grafindo Persada. Jakarta. 